\title{
Mineralogy of speleothems from four caves in the Purcă reț - Boiu Mare Plateau and the Baia Mare Depression (NW Romania)
}

\author{
Tudor TĂMAŞ 1,2* \& Răzvan UNGUREANU1 \\ ${ }^{1}$ Department of Geology, "Babeş-Bolyai” University, Kogălniceanu 1, 400084 Cluj-Napoca, Romania \\ 2“Emil Racoviță” Institute of Speleology, Clinicilor 5, 400006 Cluj-Napoca, Romania
}

Received April 2010; accepted June 2010

Available online 7 August 2010

DOI: $10.5038 / 1937-8602.55 .2 .3$

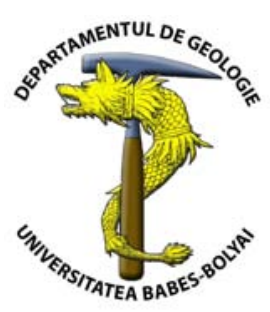

ABSTRACT. The Purcăreț - Boiu Mare Plateau and the southern edge of the Baia Mare Depression, in Sălaj and Maramureş Counties, NW Romania, host over 200 caves located in limestones ranging in age from Upper Eocene to Badenian. The carbonate rocks are interposed with non-karst rocks consisting of shales, sandstones and marls. Four caves hosted by limestones of different lithologies have been investigated for secondary minerals in the composition of their speleothems. Calcite, gypsum, goethite, jarosite, brushite, hydroxylapatite and taranakite were found in the composition of crusts, crystals, aggregates and earthy masses. The mineral association was characterized by means of X-ray diffraction and scanning electron microscopy. Gypsum, goethite and jarosite resulted from sulfide oxidation, whereas the phosphate associations formed through the interaction of phosphoric acid from bat guano with the limestones and detrital sediments. In Lii Cave, hydroxylapatite was also identified in black crusts deposited on fossil rib fragments within the limestones.

Key words: Cave minerals, goethite, sulfates, phosphates, Purcăreț-Boiu Mare Plateau, Baia Mare Depression, Romania.

\section{INTRODUCTION}

The Purcăreț - Boiu Mare Plateau (PBM) and its extension towards the southern edge of the Baia Mare Depression (BMD) (Fig. 1) represent the NW part of the Someş Plateau in N Transylvania (NW Romania). The area hosts karst features developed on Eocene, Oligocene and to a lesser extent Middle Miocene (Badenian, Sarmatian) carbonate rocks (Ghiurcă, 1970; Istvan, 1982; Giurgiu et al., 1983; Todoran and Onac, 1987; Istvan et al., 1992).

Although the karst rocks in the area are fragmented and not very extensive in terms of surface and thickness, they host many caves and potholes. Over 200 caves have been discovered and explored in the area in the past 30 years (Giurgiu et al., 1983; C.S. Montana Baia Mare, 2010). These caves have however received relatively little attention by scientists. Only three of them have been investigated with respect to the mineralogy of their speleothems, and only one in particular, Peştera Măgurici de la Răstoci (Măgurici Cave), has been thoroughly studied (Onac and Todoran, 1987; Onac, 1991; Onac and Vereş, 2003).

This paper presents data on secondary minerals from four caves (Lii, Vărai, Fântâna lui Pavel, and Vălenii Şomcutei) located in different geologic settings within the PBM and on the southern edge of the BMD.

\section{GEOLOGY}

The PBM contains dominantly monoclinal sedimentary deposits consisting of conglomerates, sandstones, shales, marls and limestones (Rusu and Popescu, 1975; Onac and Todoran, 1987; Onac et al., 1989; Istvan et al., 1992). These formations extend to the north towards the BMD, where they are transgressively covered by Badenian deposits (Fig. 1).

The Paleogene sedimentary sequences from NW Transylvania have been separated into several main units based on biostratigraphic criteria (Mészáros and Ghiurcă, 1965; Rusu, 1977; Todoran and Onac, 1989). Karst rocks occur all along the PBM within the Cozla, Cuciulat and the Bizuşa formations (Istvan et al., 1992; Onac et al., 2010). The Cozla formation (Upper Eocene - Lower Oligocene) hosts the most extensive karst phenomena. It is formed by limestones up to $60 \mathrm{~m}$ thick and frequently with a reefal character, unconformably covering the Paleogene Priabonian clastic deposits of the Jibou - Racoți - Valea Nadăşului formations (Rusu and Popescu, 1975; Onac et al., 2010). The Cozla formation consists of recurrent successions of coralgal - bioclastic "parasequences" (Bucur et al., 1989; Prică, 2001).

The Cuciulat formation, $30-50 \mathrm{~m}$ thick, consists of alternating limestones (2-5 m beds) and marls with local sandstone and coal 
intercalations. These units are overlain by the Bizusa formation (calcareous marls) and by the unkarstifiable deposits of the Ileanda (Oligocene) and Buzaş (Oligocene - Miocene) formations. The Ileanda formation typically consists of 50-60 m of bituminous shales with secondary gypsum, jarosite and native sulfur efflorescences (Rusu, 1977; Ghergari et al., 1989; Onac, 1991). The Buzaş formation comprises sandstones, marly sandstones and limy sandstones with concretions and sometimes overlies directly the Cozla limestones (Rusu, 1977).

At the southern limit of the BMD, Badenian deposits, transgressive over the Priabonian limestones, consist of alternating marls, tuffs and sandstones with a level of algal limestones in the upper part. The best display of these limestones is south from Vălenii Şomcutei (Fig. 1), where they are $10-20 \mathrm{~m}$ thick and occupy a surface of $2-3 \mathrm{~km}^{2}$ (Ghiurcă, 1969, 1970).

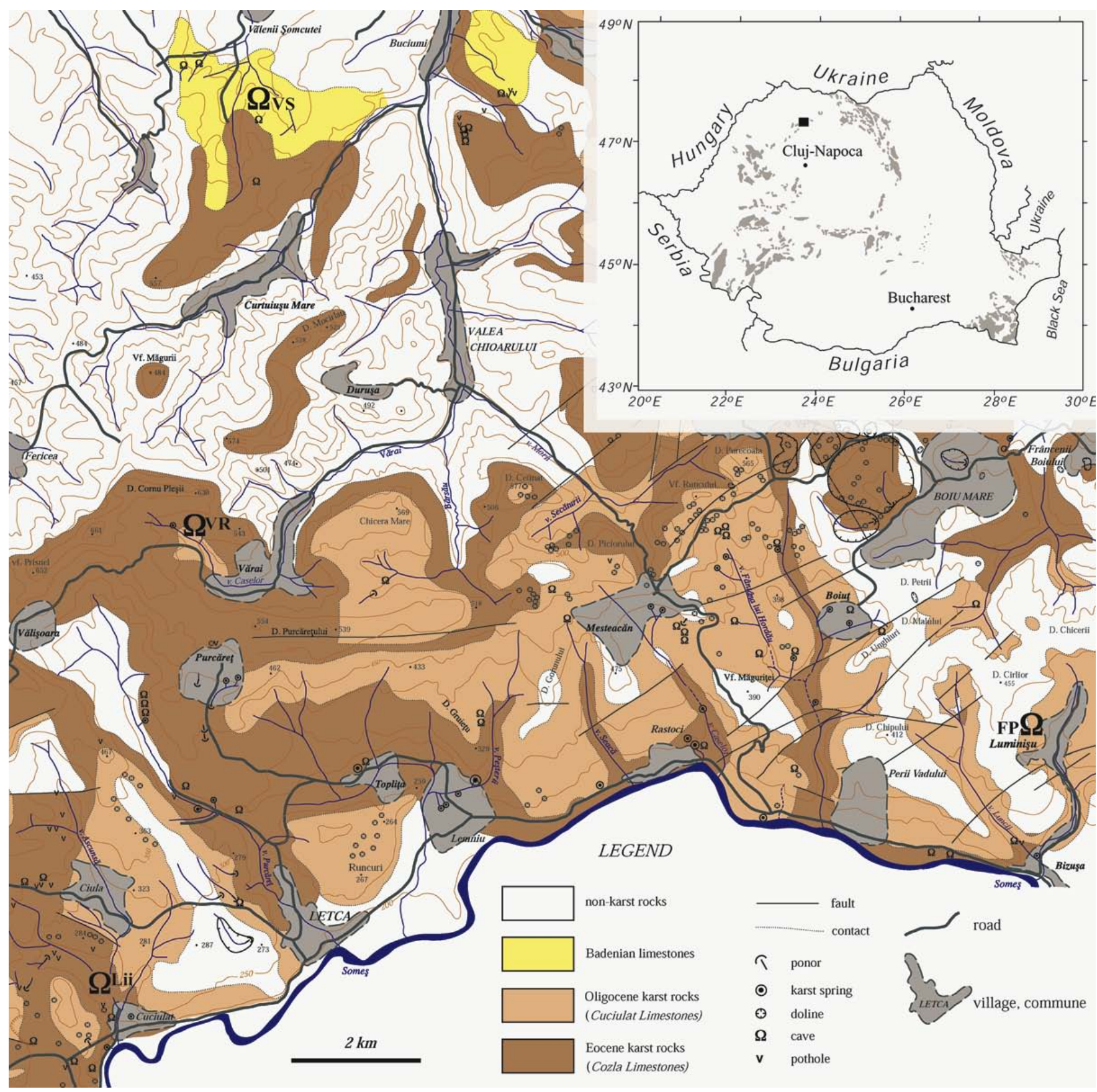

Fig. 1. Map of the PBM and southern edge of BMD with the location of the caves studied: VS - Vălenii Şomcutei Cave, VR - Vărai Cave Lii - Lii Cave, FP - Fântâna lui Pavel (modified after Onac et al. 2010).

Inset: Map of Romanian karst areas (grey) indicating the position of PBM (black square)

\section{LOCATION AND DESCRIPTION OF CAVES}

Fântâna lui Pavel (Pavel's Well), $201 \mathrm{~m}$ long and $19.5 \mathrm{~m}$ deep, is a lithologic contact cave formed in the Oligocene limestones and marls of the Cuciulat formation, with the limestones occurring only in the cave ceiling (Figs. 1, 2). First explored in 2008, it has a man-made entrance in a household well from Luminişu, Sălaj County. The well, $5.2 \mathrm{~m}$ deep, intercepts at $-4 \mathrm{~m}$ an active cave passage, $4-5 \mathrm{~m}$ wide and 1.4-1.7 m high, which gets progressively smaller downstream until a terminal sump is encountered. The cave stream is captured underground in a sinkhole from the vicinity of the entrance. The cave is formed only 10-12 m below the surface and is quite dangerous due to unstable breakdown and flooding events that completely fill the cave with water. 
Fântâna lui Pavel has very few common speleothems, such as small calcite stalactites and crusts formed on plant roots (rootsicles), as well as thin flowstones formed on the bottom of the passage. Seven samples were collected, including earthy crusts, wall nodules and aggregates, white, yellow or dark brown in color.

Peştera din Valea Rea de la Vălenii Şomcutei (Vălenii Şomcutei Cave) is located near the village of Vălenii Şomcutei, $3 \mathrm{~km}$ west of Ş omcuta Mare, in Maramureş County (Figs. 1, 2). It was first mapped in 1977 by C.S. Montana Baia Mare and a detailed description of the cave was published by Istvan (1982). It is a spring cave with a single passage mainly developed N-S, declared a natural monument in 1977. The cave is formed in Badenian algal (Lithothamnium) limestones, is $175 \mathrm{~m}$ long and hosts two bat colonies. We collected 13 samples mostly from the areas of the bat droppings.
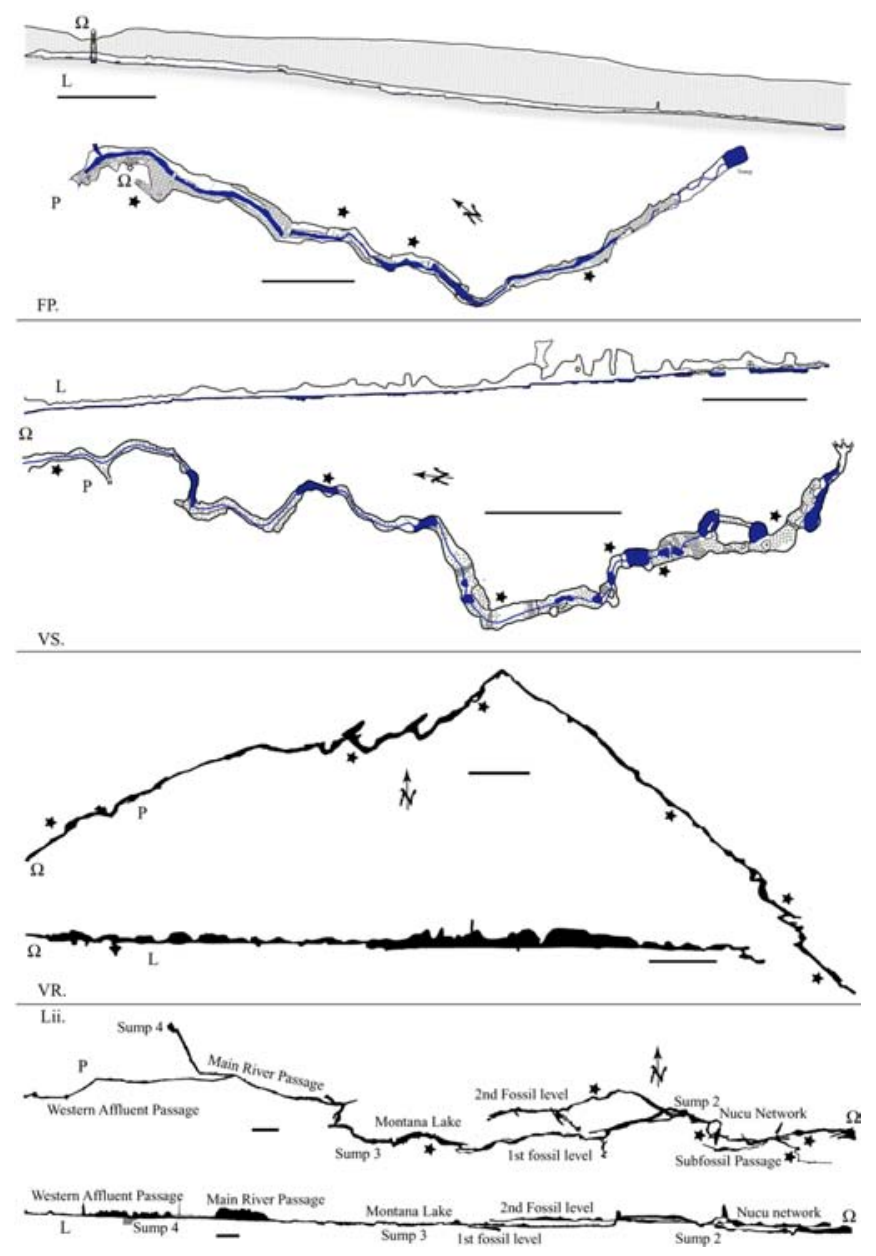

Fig. 2. Maps of the caves studied (FP - Fântâna lui Pavel,

VS - Vălenii Şomcutei Cave, VR - Vărai Cave, Lii - Lii Cave;

$P$ - plan view, $L$ - longitudinal section, $\Omega$ - cave entrance; black stars represent sample locations; all black scale bars $=20 \mathrm{~m}$ ). All maps courtesy of C.S. Montana Baia Mare.

Peştera Lii (Lii Cave) is located close to Cuciulat village, Sălaj County. Hosted by Cozla limestones, Lii Cave is the third longest cave in the area (Figs. 1, 2). Passages grouped on four karstification levels have been explored by CS Montana Baia Mare between 1990 and 1994 (Constantinescu et al., 1992, 1995) and more recently in 2009, when the cave reached the length of $1510 \mathrm{~m}$. Its western half consists of two independent active passages developed on tall and narrow canyons with vadose flow, the western one blocked upstream by several boulder chokes and the northern by a sump. After a $90^{\circ}$ turn south at the end of the Main River Passage, the cave stream disappears in a tiny passage ended by another sump. The eastern half of the cave consists of three distinct, discontinuous levels separated by a mere $9 \mathrm{~m}$, fragmented by sumps and breakdowns (Fig. 2). The two upper levels connect upstream sump 2, while the lower fossil and the subfossil levels connect by a narrow fissure upstream sump 1, 50 m from the entrance. Overall, the fossil passages each show a onestep phreatic development phase, followed by intermittent flooding stages.

Calcitic speleothems occur especially in the Nucu Network and to a lesser extent in the final part of the $2^{\text {nd }}$ Fossil level (Fig. 2). Twelve samples were collected from the fossil and subfossil passages of the cave, consisting of various black, brown and grey wall crusts, as well as some rib fragments, probably of Dugongidae, from the Cozla limestones. We note that neither guano deposits, nor bats have been reported from the deeper parts of Lii Cave and the three subfossil - fossil passage levels are normally separated from the entrance part by two sumps supplied with water only at extreme floods.

Peştera de la Vărai (Vărai Cave) $433 \mathrm{~m}$ long, is formed in Priabonian limestones at the western end of its namesake village, in Maramureş county (Figs. 1, 2). As is the case with many other caves in the area, it consists of a single, nearly horizontal passage. The cave is oriented first NE, then SE, and receives a variable amount of water from fissures in the ceiling near the entrance. The water flows through an impenetrable pit at $\sim 60 \mathrm{~m}$ from the entrance and the rest of the cave is fossil, with the floor and part of the walls covered with clay deposits. A recent dig at the end of the cave has opened a previously unknown sector, which intercepts an active shaft draining water from some yet unexplored passages situated above the main passage level. Vărai Cave has only two areas with calcitic speleothems, one right at the entrance and the second at the former end of the cave. At the latter site, sampling has revealed that classic speleothems (flowstone, stalactites, drapes) consist mainly of goethite, covered at the surface by millimetric calcite layers. Aside from the two areas mentioned, the cave lacks typical carbonate speleothems, the 6 samples collected being thin black crusts and gypsum crystals.

\section{ANALYSIS METHODS}

Sub-sample separations for mineral analyzes were done with a Nikon SMZ1500 stereo zoom binocular microscope. Subsamples were analyzed by means of Xray powder diffraction (XRD), scanning electron microscopy (SEM) and energy dispersive spectroscopy (EDS). For XRD analyzes we used a Rigaku Miniflex II (30 kV and $15 \mathrm{~mA}$ ), with $\mathrm{CuK} \alpha_{1}, \lambda=1.54059$ (University of South Florida), using silicon (NBS-640b) as an internal standard. Powder diffractions have been done in the range of $5-70^{\circ} 2 \theta$ with a step of $0.02^{\circ} 2 \theta / \mathrm{s}$. Mineral species were identified based on the PDF2 (2005) database. SEM and EDS analyzes were carried out with a JEOL JSM 5510LV at the Electron Microscopy Center, Babeş-Bolyai University, using Quanta 300 software for chemical data collection. 


\section{RESULTS}

The secondary minerals identified in the four caves from the PBM and BMD are calcite, gypsum, jarosite, goethite, brushite, hydroxylapatite and taranakite. Pyrite and marcasite occur in nodules formed within the Oligocene marls of the Cuciulat formation opened by Fântâna lui Pavel. They are also known to occur in large amounts in the rocks of the Ileanda formation (Ghergari et al., 1989; Onac, 1991), from which they are transported in the caves as detrital sediments.

As a general rule, the caves of the PBM and BMD have few decorations, Ciungi Cave and Bătrânilor Cave being notable exceptions (Istvan and Zachan, 1983; Merşei et al., 1993; C.S. Montana Baia Mare, 2010). Calcite occurs in all investigated caves as common speleothems, such as stalactites, stalagmites, wall crusts and flowstones. More frequent calcite speleothems occur in the upstream part of Vălenii Şomcutei Cave, in the first sector of the $1^{\text {st }}$ Fossil level of Lii Cave and close to both ends of Vărai Cave. The largest variety of calcite speleothems was noted in the entrance part of Vărai Cave, where helictites are abundant together with other more common calcite speleothems. No other carbonates were identified in the samples.

Pyrite (cubic, $\mathrm{FeS}_{2}$ ) and marcasite (orthorhombic, $\mathrm{FeS}_{2}$ ) have both been identified in Fântâna lui Pavel, composing the ferruginous nodules from the Oligocene marls (Fig. 3).

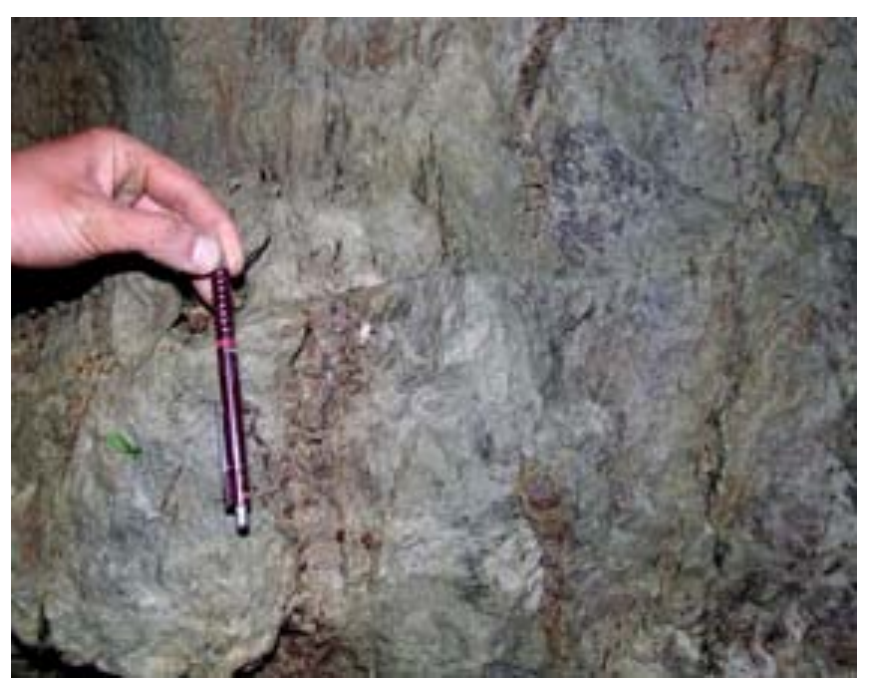

Fig. 3. Sulfide nodules in Oligocene marls (Fântâna lui Pavel).

Their oxidation in contact with the cave seepage water represents the source for goethite, gypsum and jarosite identified in this cave. The oxidation is not complete, as indicated by the XRD of both goethite and especially pyrite samples, which could not be separated macroscopically (Fig. 4). From the position of the respective secondary minerals towards the edge of the nodules, one can note a certain order of secondary mineral deposition, which would point to a progressive decrease of the acidity of the solution. Jarosite formed in the central part, followed by goethite as the $\mathrm{pH}$ of the solution increased and then by gypsum at the contact with the host marls.

Gypsum $\mathrm{CaSO}_{4} \cdot 2 \mathrm{H}_{2} \mathrm{O}$ is the second most frequent mineral in the caves from PBM and BMD, after calcite. It was previously reported - based on visual identification, physical properties or XRD data - from 6 caves in the area: Măgurici (Onac and Todoran, 1987; Onac and Vereş, 2003), Zănoaga Pietricelii, Ciungi, Unghiuri, Dealul Marginea
(Istvan and Damian, 1990) and Moara lui Pocol caves (Istvan, 1994). In the caves mentioned, gypsum occurs as euhedral crystals and intergrowths, wall and ceiling crusts and sometimes as aggregates in detrital sediments. Here we report two new occurrences of gypsum, in Fântâna lui Pavel and Vărai caves, where it was identified by means of XRD. In Vărai Cave, gypsum occurs as wall crusts and centimetric, euhedral, perfectly transparent single crystals buried in clay sediments. The crystals are lenticular with both terminations present, with the dominant faces (110) and (111) exhibiting striations, which may indicate episodic crystallization. In Fântâna lui Pavel, small lamellar gypsum crusts were found in close connection with sulfide nodules from the Oligocene marls. Gypsum is deposited only at the nodule edge, where the marls provided the calcium for its formation.

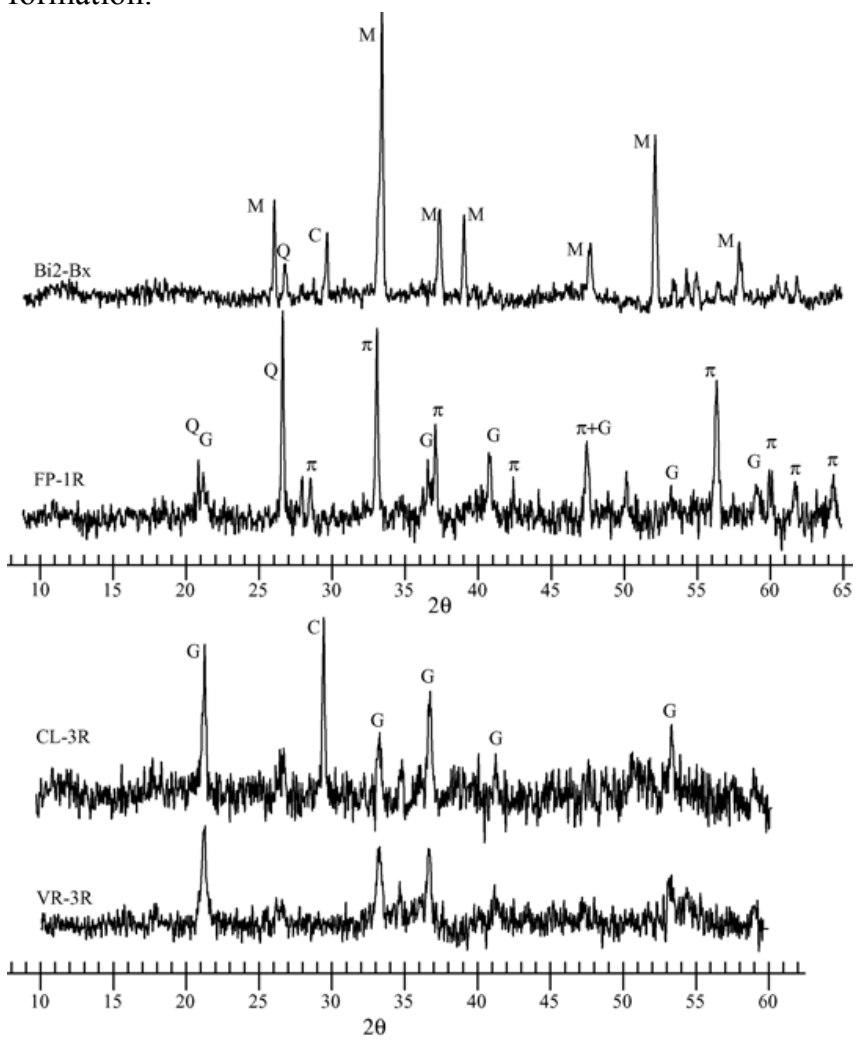

Fig. 4. XRD patterns of goethite $(G)$ from Vărai Cave (VR-3R), Lii Cave (CL-3R) and Fântâna lui Pavel (FP-1R), and pyrite ( $\pi$ ) and marcasite (M) from Fântâna lui Pavel (FP-1R, Bi2-Bx; C-calcite, $Q$-quartz).

Goethite $\alpha-\mathrm{FeO}(\mathrm{OH})$ was identified in wall crusts from Lii and Vărai caves, as well as in the oxidized sulfide nodules from Fântâna lui Pavel. In Lii and Vărai caves, goethite is the main mineral in the composition of black and brown wall crusts at the contact with cave sediments. The most spectacular occurrence is the one in the former end of Vărai Cave, where goethite is the constituent of 30 to $50 \mathrm{~cm}$ long stalactites, draperies and flowstone. Most speleothems blocking the passage consist of goethite as a main mineral, covered by a thin crust of calcite.

Jarosite $\mathrm{KFe}_{3}\left(\mathrm{SO}_{4}\right)_{2}(\mathrm{OH})_{6}$ was identified in Fântâna lui Pavel as a yellow powder covering the centre of the sulfide nodules. Its identification was based on its XRD lines, although it was present in small amount. Jarosite is generally known to form in strongly acidic environments, while goethite requires weakly acidic or neutral environments (Hill and Forti, 1997). With very few 
exceptions, jarosite in caves result from sulfide oxidation or from sulfur-bearing solutions (Hill and Forti, 1997; Polyak and Provencio, 1998).

Two new phosphate associations, in Vălenii Şomcutei and Lii caves, are reported in this paper (Fig. 5).

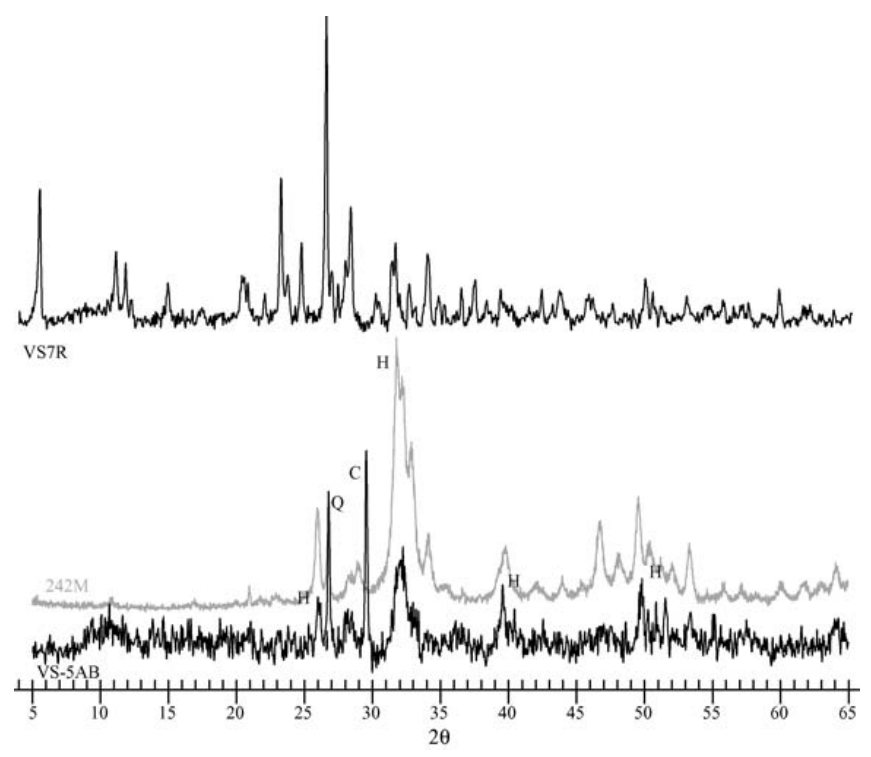

Fig. 5. XRD patterns of taranakite from Vălenii Şomcutei Cave (VS7R) and hydroxylapatite (H) from Lii Cave (242M) and Vălenii Şomcutei Cave (VS-5AB) ( $Q$-quartz, C-calcite).

In Vălenii Şomcutei Cave, phosphate minerals are linked to two small guano accumulations. The first one occurs on the left side of the cave passage, on a steep terrace above the cave stream. The guano deposit covers previously deposited calcite flowstone and silty clay sediments. Small yellowish white taranakite powdery nodules were found at the contact with guano and in dessication cracks in the silty clays. A common cave phosphate, taranakite $\mathrm{K}_{3}\left(\mathrm{Al}, \mathrm{Fe}^{3+}\right)_{5}\left(\mathrm{PO}_{4}\right)_{2}\left(\mathrm{HPO}_{4}\right)_{6} \cdot 18 \mathrm{H}_{2} \mathrm{O}$ has been reported previously from the area in Măgurici Cave by Onac and Vereş (2003) and Johnston et al. (2010), where it occurs in the same conditions as in Vălenii Şomcutei Cave. A SEM picture of taranakite shows thin platy hexagonal crystals reaching about $1 \mathrm{~mm}$ in size (Fig. 6). Phosphoric acid from the guano interacting with the silty clay is at the origin of taranakite, which form in the presence of an excess of alkali ions (Murray and Dietrich, 1956).

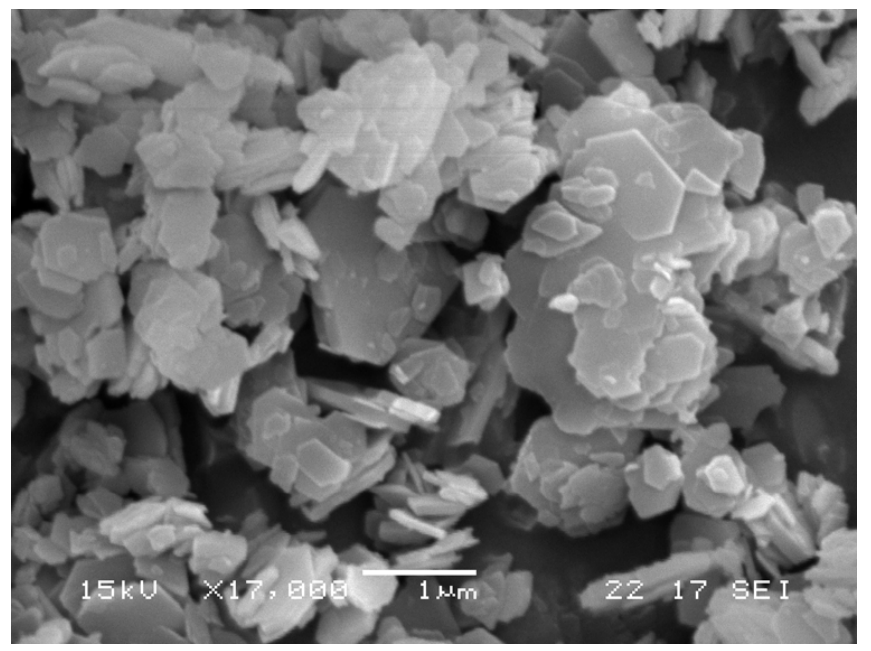

Fig. 6. SEM. Taranakite crystals (Vălenii Şomcutei Cave).
Brushite $\mathrm{CaHPO}_{4} \cdot 2 \mathrm{H}_{2} \mathrm{O}$ has been identified in Lii Cave, where it forms white-grey wall crusts in a small room close to sump 2, on the $1^{\text {st }}$ fossil level. Brushite is a common cave mineral and results from the interaction of phosphoric acid from guano with the limestones or carbonate speleothems, at a $\mathrm{pH}$ below 6 (Hill and Forti, 1997). Its only other reported occurrence in the area is in Măgurici Cave (Onac and Vereş, 2003; Johnston et al., 2010).

Hydroxylapatite $\mathrm{Ca}_{5}\left(\mathrm{PO}_{4}\right)_{3}(\mathrm{OH})$ (Fig. 5) was found in Vălenii Şomcutei Cave at both guano sites, at the first site as thin red-brown flowstone covering calcite speleothems below the guano pile and at the second site as brown-black skin-like crusts covering the passage walls. It generally forms through the reaction of phosphoric acid from guano with the limestone walls of the cave, at a $\mathrm{pH}$ above 6 (Hill and Forti, 1997). In Lii Cave hydroxylapatite also has two different occurrences. The first one is in black wall crusts in an area of the $1^{\text {st }}$ fossil level near sump 2, where we assumed it is probably a result of bat droppings. The second occurrence is again as milimetric black crusts, but covering fossil ribs protruding from the wall of the $2^{\text {nd }}$ fossil level passage (Fig. 7). Although the XRD of the fossil material is nearly similar, the difference resides in the morphology of the deposit (millimetric crusts easily detaching from the bone, and also of a different color). On the exposed surfaces, the bones appear to have reacted at some extent with carbonate-rich water.

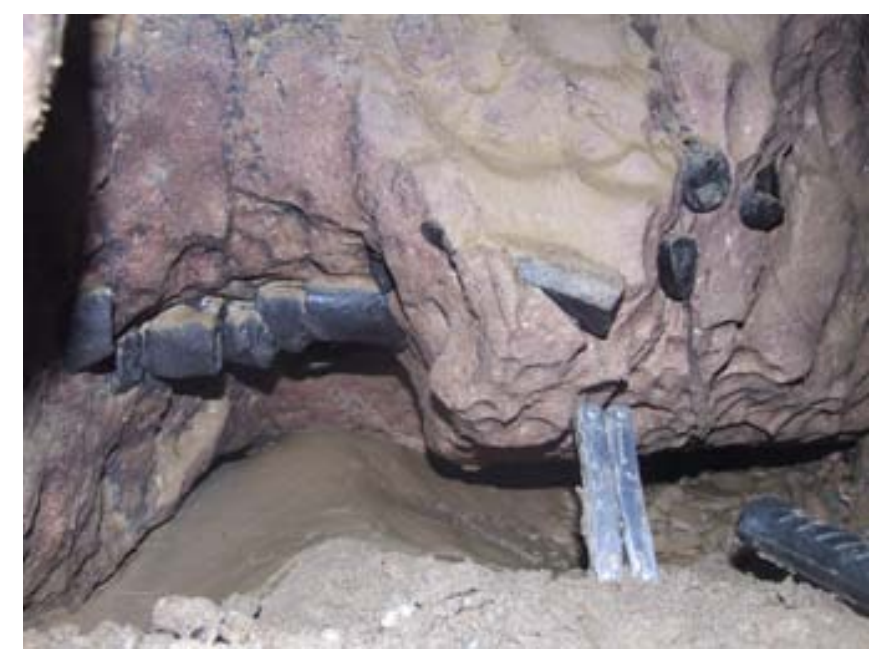

Fig. 7. Black hydroxylapatite crusts on fossil rib fragments (Lii Cave).

\section{CONCLUSIONS}

With few exceptions, the caves of the Purcăreț - Boiu Mare Plateau and Baia Mare Depression are generally small and their speleothems are not a very common feature. However the mineralogical study of wall crusts and powdery deposits in four caves from the area has revealed several mineral associations. Our preliminary study has uncovered calcite, goethite, gypsum, jarosite, brushite, taranakite and hydroxylapatite as secondary minerals in the composition of speleothems sampled, along with primary pyrite, marcasite and detrital quartz in variable amounts.

Gypsum speleothems were found in two of the four caves studied. In Vărai Cave, gypsum crystals and crusts were found inside clay deposits and also directly on the limestone walls. Their origin can be linked to the reaction of limestones with sulphuric acid resulted from sulphide oxidation. The source of sulphides in the cave sediments are 
probably the Oligocene rocks, represented by a patch of Cuciulat formation, in the area above the cave. The large amount of goethite speleothems at the former end of Vărai Cave however leads to a different supposition, of larger sulphide deposits along the seepage water path, which still needs to be verified. By contrast, in Fântâna lui Pavel, the origin of the jarosite-goethite-gypsum association is rather straightforward, as they resulted directly from the oxidation of pyrite and marcasite from nodules in the Oligocene marls. The two new phosphate associations from Lii Cave and Vălenii Şomcutei Cave add to the only one described in the area prior to this study, from Măgurici Cave. Three phosphates were identified - brushite, taranakite and hydroxylapatite - genetically linked to phosphoric acid resulted from guano accumulations interacting with the limestones and detrital sediments from the caves (Vălenii Şomcutei Cave and possibly Lii Cave) and also to fossil bones. This latter occurrence is rather peculiar, as the hydroxylapatite crusts were formed on fossil rib fragments from the Cozla limestones.

These results represent a contribution to the mineralogy of speleothems from the caves of the Purcăret - Boiu Mare Plateau and the Baia Mare Depression, in NW Romania. The large number of caves, the great lithological variety of host rocks in the area and the scarcity of data already at hand hold promise for future interesting findings.

Acknowledgements. The authors thank the cavers from C.S. Montana Baia Mare for the cave maps and field assistance and Mara Matei for sampling permission in Fântâna lui Pavel. We are very grateful to Bogdan P. Onac for use of lab resources at the University of South Florida in Tampa, and to Lucian Barbu at the Electron Microscopy Center, Babeş-Bolyai University, Cluj-Napoca, who assisted with scanning electron microscopy. Suggestions on the manuscript from Dumitru Istvan, Vlad Codrea, and two anonymous reviewers are greatly appreciated.

\section{R E F E R E N C E S}

Bucur, I.I., Onac, B. \& Todoran, V. 1989, Algues calcaires dans les dépôts oligocènes inférieurs de la région Purcăreț-Mesteacăn-Valea Chioarului (NW du Basin de Transylvanie). In The Oligocene from the Transylvanian Basin (Petrescu, I., Ed.), p. 141-148, Cluj-Napoca.

C.S. Montana Baia Mare 2010, Cave inventory and systematics (1976-2010). Ms. Excel Document. Montana Caving Club Archives, Baia Mare (in Romanian).

Constantinescu, E., Rist, I., Istvan, D. \& Todoran, M. 1992, New discoveries in Lii Cave (Someş Plateau). Cercetări Speologice, 1: 41-43 (in Romanian).

Constantinescu, E., Istvan, D., Rist, I. \& Gergely, R. 1995, Hydrodynamic and genetic observations in Lii Cave (Someş Plateau). Cercetări Speologice, 3: 41-44 (in Romanian).

Ghergari, L., Petrescu, I. \& Todoran, V. 1989, Mineralogicalpetrographical studies on the Oligocene clay rocks of the Curtuiuş, Bizuşa and Ileanda Beds with a view to reconstitute the paleoenvironment. In The Oligocene from the Transylvanian Basin (Petrescu, I., Ed.), p. 459-468, Cluj-Napoca.

Ghiurcă, V. 1969, Geology of the Baia Mare Neogene basin. Unpublished PhD Thesis, University of Bucharest, 397 p. (in Romanian).
Ghiurcă, V. 1970, Contribution géologique á l'étude du karst initial engendré par les formations miocènes du bassin de Baia Mare. In Livre du centenaire Émile $G$. Racovitza 1868-1968, Académie de la République Socialiste de Roumanie, Bucarest, p. 669-673.

Giurgiu, I., Vădeanu, T., Done, A., Negru, M., Sandeschi, N., Silvăşanu, G., Codescu, M., Ciuculescu, O., Sfâşie, M., Cucu, F. 1983, Speleological discoveries and explorations in the Someş Plateau. Buletinul Clubului de Speologie "Emil Racoviță” Bucureşti, 8: 11-81 (in Romanian).

Hill, C.A., Forti, P. 1997, Cave minerals of the world $\left(2^{\text {nd }}\right.$ ed.), National Speleological Society, Huntsville Alabama, $463 \mathrm{p}$.

Istvan, D. 1982, The karst from Vălenii Şomcutei (Someş Plateau). Carst - Anuarul clubului de speologie CEPROMIN Cluj-Napoca, 2: 61-67 (in Romanian).

Istvan, D. 1994, Letca 1992 (Someş Plateau). Cercetări Speologice, 2: 23-29 (in Romanian).

Istvan, D., Damian, S. 1990, Mineralogical data on the gypsum from Zănoaga Pietricelii Cave (Someş Plateau), Peştera - Buletinul Clubului de Speologie "Emil Racoviță" Cluj-Napoca, 3: 130-136 (in Romanian).

Istvan, D., Zachan, A. 1983, The caves from the Mesteacăn village area (Maramureş county). Buletinul Clubului de Speologie "Emil Racoviță” Bucureşti, 8: 98-106 (in Romanian).

Istvan, D., Rist, I., Constantinescu, E., Gellinek, G., Merşei, F., Tămaş, I., Borz, I., Diaconescu, M., Todoran, M., Zenecan, D. \& Moldovan, C. 1992, Update of the cave inventory from the 4001 hydrographic basin (right side of Someş river, between Bizuşa and Jibou). Cercetări Speologice, 1: 50-84 (in Romanian).

Johnston, V.E., McDermott, F. \& Tămaş, T. 2010, A radiocarbon dated bat guano deposit from NW Romania: Implications for the timing of the Little Ice Age and Medieval Climate Anomaly. Palaeogeography, Palaeoclimatology, Palaeoecology, 291 (3-4): 217-227.

Merşei, F., Istvan, D., Rist, I., Nistor, Gh., Paal, E., Mocean, M. \& Constantinescu, E. 1993, Bătrânilor Cave from Scurtă Valley (Toplița, Someş Plateau). Contribuții la cunoaşterea carstului, 1: 47-48 (in Romanian).

Mészáros, N., Ghiurcă, V. 1965, The Paleogene of the area between the Țicău and Preluca massives. Studia Universitatis Babeş-Bolyai, Geologia-Geographia, X: 29-43 (in Romanian).

Murray, J.W., Dietrich, R.V. 1956, Brushite and taranakite from Pig Hole Cave, Giles County, Virginia. American Mineralogist, 41 (7-8): 616-626.

Onac, B.P. 1991, New data on some gypsum speleothems in the Vîntului (Pădurea Craiului Mountains) and Răstoci (Someşan Plateau) caves. Travaux de l'Institute de Spéologie "Emile Racovitza", XXX: 189-193.

Onac, B.P., Todoran, V. 1987, Contributions à la connaissance des formations de gypse de la Grote de Răstoci (NO de la Roumanie). In The Eocene from the Transylvanian Basin (Petrescu, I., Ed.), p. 301-306, Cluj-Napoca.

Onac, B.P., Vereş, D. 2003, Sequence of secondary phosphates deposition in a karst environment: evidence from Măgurici Cave (Romania). European Journal of Mineralogy, 15: 741-745.

Onac, B.P., Todoran, V. \& Onac, L. 1989, Review of the karst on the Oligocene formations from the Someş

Studia UBB, Geologia, 2010, 55 (2), 43 - 49 
Plateau - Romania. In The Oligocene from the Transylvanian Basin (Petrescu, I., Ed.), p. 503-512, Cluj-Napoca.

Onac, B.P., Vereş, D., Tămaş, T., C.S. Montana Baia Mare \& Todoran, V. 2010, The hydrogeology of CuciulatPurcăreț-Boiu Mare karst area, northern part of the Someş plateau, Romania. In Karst hydrogeology of Romania (Orăşeanu, I, Iurkievicz, A., Eds.), Belvedere, Oradea, p. 329-341.

Polyak, V.J., Provencio, P. 1998, Hydrobasaluminite and aluminite in caves of the Guadalupe Mountains, New Mexico. Journal of Cave and Karst Studies 60 (1): 51-57.

Prică, I. 2001, Coralgal facies of the upper Eocene - lower Oligocene limestones in Letca - Răstoci area. Studia Universitatis Babes Bolyai, Geologia, XLVI (2): 53-61.
Rusu, A. 1977, La stratigraphie des depots oligocènes du nord-ouest de la Transylvanie (la region de TrăzneaHida-Poiana Blenchii). Anuarul Institutului de GeologieGeografie, LI: 69-223.

Rusu, A., Popescu, B. 1975, Geologic Map of Romania, scale 1:50.000, Jibou Sheet. Romanian Geological Institute.

Todoran, V., Onac, B.P. 1987, La morphologie de l'exo- et de l'endokarst du Plateau de Purcăreț-Mesteacăn (Plateau du Someş). Theoretical and Applied Karstology, 3: 127-131.

Todoran, V., Onac, B.P. 1989, Eocene/Oligocene boundary in the Purcăreț-Mesteacăn area (The Someş Plateau). In The Oligocene from the Transylvanian Basin (Petrescu, I., Ed.), p. 129-132, Cluj-Napoca. 